\title{
OpenDocs
}

Title: Cyclone disaster vulnerability and response experiences in coastal Bangladesh

Citation: Alam, E. and Collins, A. E. (2010), Cyclone disaster vulnerability and response experiences in coastal Bangladesh. Disasters, 34: 931-954. doi:10.1111/j.1467-

7717.2010.01176.x

Official URL: http://dx.doi.org/10.1111/j.1467-7717.2010.01176.x

More details/abstract: For generations, cyclones and tidal surges have frequently devastated lives and property in coastal and island Bangladesh. This study explores vulnerability to cyclone hazards using firsthand coping recollections from prior to, during and after these events. Qualitative field data suggest that, beyond extreme cyclone forces, localised vulnerability is defined in terms of response processes, infrastructure, socially uneven exposure, settlement development patterns, and livelihoods. Prior to cyclones, religious activities increase and people try to save food and valuable possessions. Those in dispersed settlements who fail to reach cyclone shelters take refuge in thatched-roof houses and bigbranch trees. However, women and children are affected more despite the modification of traditional hierarchies during cyclone periods. Instinctive survival strategies and intracommunity cooperation improve coping post cyclone. This study recommends that disaster reduction programmes encourage cyclone mitigation while being aware of localised realities, endogenous risk analyses, and coping and adaptation of affected communities (as active survivors rather than helpless victims).

Version: Submitted version

Terms of use: This is the peer reviewed version of the following article: Alam, E. and Collins, A. E. (2010), Cyclone disaster vulnerability and response experiences in coastal Bangladesh. Disasters, 34: 931-954, which has been published in final form at http://dx.doi.org/10.1111/j.1467-7717.2010.01176.x. This article may be used for noncommercial purposes in accordance with Wiley Terms and Conditions for Self-Archiving.

This is a download from OpenDocs at the Institute of Development Studies 


\section{Cyclone disaster vulnerability and response experiences in coastal Bangladesh}

Edris Alam Assistant Professor and Disaster and Development Centre Affiliate, Department of Geography and Environmental Studies, University of Chittagong, Bangladesh and Andrew E. Collins Reader in Disaster and Development, Disaster and Development Centre, School of Applied Sciences, Northumbria University, United Kingdom

For generations, cyclones and tidal surges have frequently devastated lives and property in coastal and island Bangladesh. This study explores vulnerability to cyclone hazards using first-hand coping recollections from prior to, during and after these events. Qualitative field data suggest that, beyond extreme cyclone forces, localised vulnerability is defined in terms of response processes, infrastructure, socially uneven exposure, settlement development patterns, and livelihoods. Prior to cyclones, religious activities increase and people try to save food and valuable possessions. Those in dispersed settlements who fail to reach cyclone shelters take refuge in thatched-roof houses and big-branch trees. However, women and children are affected more despite the modification of traditional hierarchies during cyclone periods. Instinctive survival strategies and intra-community cooperation improve coping post cyclone. This study recommends that disaster reduction programmes encourage cyclone mitigation while being aware of localised realities, endogenous risk analyses, and coping and adaptation of affected communities (as active survivors rather than helpless victims).

Keywords: coastal and island people of Bangladesh, coping, cyclone vulnerability, local response

\section{Introduction}

With the effects of natural hazards rising in terms of loss of life and injuries in poorer nations (ISDR, 2002; World Bank, 2005; CRED, 2007), institutional disaster reduction approaches (ISDR, 2004; UNDP, 2004; DFID, 2005) and approaches adaptable to individual social and livelihood experiences are required. Vulnerability factors have been central to the development of disaster research (Khan, 1974; Burton, Kates and White, 1993; Hewitt, 1997; Twigg and Bhatt, 1998; Weichselgartner, 2001, Wisner et al., 2004; IFRC, 2006). However, despite good progress in cyclone preparedness, exemplified by the existing comprehensive disaster management policies of the Government of Bangladesh, localised vulnerability factors in cyclone hazards arguably remain only partly considered. Endogenous cyclone response experiences could be more central to cyclone interventions in Bangladesh. 
Enhanced local-level adaptation to cyclone hazards through established coping will be crucial for resilience to any suspected increase in cyclone hazards. This paper explores the context of vulnerability and local coping strategies in relation to cyclone response experiences in Bangladesh over the past two decades. The broad analysis of the study is consistent with other findings concerning vulnerability and disaster response in the country (Zaman, 1988; Haque and Zaman, 1994; Hutton and Haque, 2003, 2004; Edgeworth and Collins, 2006). The findings in this paper complement disaster mitigation studies in Bangladesh, although with further grounded detail and thoughts based on the realities of survival in the cyclone belt.

Bangladesh is currently ranked as one of the world's most disaster-prone countries, with 97.1 per cent of its total area and 97.7 per cent of the total population at risk of multiple hazards, including cyclones (World Bank, 2005). From 1891-98, approximately 178 severe cyclones with wind speeds of more than 87 kilometres per hour $(\mathrm{km} / \mathrm{h})$ formed in the Bay of Bengal, causing extensive loss of life and destruction of property. From 1970-98, there was devastation due to 38 severe cyclones. After such an event in April 1991, material damage was about USD 2.4 billion and human casualties numbered around 140,000. In 1970, a similar catastrophe claimed some 500,000 lives (Choudhury, 1998). In addition, storm surge, an unusual rise in seawater associated with a tropical cyclone originating in the Bay of Bengal, has also caused major devastation in the coastal region (Islam, 1974; Choudhury, 1998, Alam, 2003). On 15 November 2007, Cylone Sidr struck the coastal region, the worst of its type since 1991 , with winds of $250 \mathrm{~km} / \mathrm{h}$-155 miles per hour (mph)—and a five metre sea surge, killing more than 3,300 people (Reuters News Agency, 2008). Millions of people were affected, approximately one million tonnes of rice was lost, and by January 2008 nearly 500,000 people were estimated still to be living in temporary accommodation, such as in tents made of polythene.

The current aim of the main disaster management government agency of Bangladesh, the Disaster Management Bureaux of the Ministry of Food and Disaster Management (MoFDM), is to achieve a paradigm shift in disaster management: from conventional response and relief to a more comprehensive risk reduction culture. In doing so, it underscores capacity-building of affected people to create resilience to disasters (MoFDM, 2007). This reflects the adoption of the 'Hyogo Framework for Action 2005-2015' in national policies, emphasising the need to reduce vulnerability and promote resilience (UNISDR, 2005). Yet, without in-depth understanding of the underlying vulnerabilities to natural hazards, the basis of local people's perceptions and behaviour, and the goals that they set, disaster reduction strategies are 
considered unlikely to succeed (Khan, 1973; White, 1974; Burton, Kates and White, 1993; Blaikie et al., 1994).

Any given risk or disaster event is distinguished by its geographic location and setting. These are important keys to the origins of danger, the forms of damage and whom they most affect. They are critical for the appropriateness and deployment of organised response (Hewitt, 1997, p. 12).

Indeed most disaster commentators have implied, if not directly highlighted, that it is essential that planners, policymakers and development practitioners endeavour to understand local uses of the environment, local knowledge and local practices (White, 1974; Chambers, 1983; Sillitoe, 2001). Furthermore, the underlying causes of vulnerability to disasters more locally are often economic and societal, such as through landlessness, fragmentation of community cohesion, and lack of access to political representation.

Despite its renowned experience and ongoing progress for coping with disaster, Bangladesh still experiences a dearth of optimal coordination among physical, societal and technological systems in its most hazardous zones. Public adjustments occur, but less so with regard to people's perceptions or behaviour, these being cited as important factors responsible for the failure of past hazard mitigation strategies (Khan, 1974; Paul, 1984; Haque and Zaman, 1993; Hutton and Haque, 2004). Therefore, an analysis of the relationship between cyclone hazards and human behaviour in the coastal areas, using local-level and personalised accounts, appears to be an imperative for developing improved disaster reduction strategies. The rationale here is that understanding vulnerability and human responses in direct context leads to more applied application of the basic components frequently alluded to in disaster risk reduction frameworks (IFRC, 2002; ISDR, 2004; UNDP, 2004; DFID, 2005).

\section{Theoretical human response to hazards}

Burton, Kates and White (1993, p. 48) presented the view that hazard response 'encompasses all the ways in which a society may act to reduce the effects or increase the benefits of a hazard'. These include actions immediately before hazards (such as warning signals, emergency evacuation or other precautionary measures), or long-term actions (such as planting crops less susceptible to drought), or adaptation to extreme environments (such as building villages on levees). Hence, human responses for living with natural hazards have been differentiated as both short- and long-run actions involving the use of 'adjustment' and 'adaptation' respectively. For example, 'designing a house to resist a storm surge would be an adjustment; locating and organising a community over a long period of time so that its 
houses are beyond the storm surge would be an adaptation' (Burton, Kates and White, 1993, p. 49). Adaptation also refers to the manifestation of adaptive capacity (Smit and Wandel, 2006), meaning the capacity of a system to deal with, accommodate, adapt to and recover (Jones, 2001; Smit et al., 2000).

Meanwhile, 'coping is the manner in which people act within the limits of existing resources and range of expectations to achieve various ends. In general this involves no more than "managing resources", but usually it means how it is done in unusual, abnormal and adverse situations' (Wisner et al., 2004, p. 113). 'Thus coping can include defence mechanisms, active ways of solving problems and methods for handling stress' (Murphy and Moriarty, 1976, quoted in Wisner et al., 2004, p. 113). Hewitt (1997, p. 36) defined coping as 'the actions of ordinary people or disrupted remains of institutions, in contrast to official and planned response'. In the present study, local people's responses entail the activities (survival strategies) of household members and the interventions of relatives, neighbours and other social networks to mitigate loss in a disaster period.

\section{Cyclone hazard studies in Bangladesh}

Human responses to natural hazards were investigated in 1974 in 14 countries around the world (White, 1974): residents in hazardous areas were asked what could be done. Bangladesh was one of the study sites. Islam (1974) prepared a Bangladesh country paper entitled 'Human adjustment to cyclone hazards: a case study of Char Jabbar'. More recently, Haque (1995, 1997) and Haque and Blair (1992) analysed climatic hazard warning processes, hazard preparedness and coastal people's reactions to warnings based on quantitative surveys following the April 1991 cyclone. These studies reveal that, although a hazard warning process was successful in principle, disbelief of warnings, fear of burglary, and a lack of cyclone shelters were among the factors identified by affected people as resulting in greater loss. Communities vulnerable to cyclones also face a broader risk landscape. In the context of this study, crime, including boat theft and resultant loss of livelihood, serves to exemplify some of the other issues that can threaten a household.

A review by Dove and Khan (1995) debates the April 1991 cyclone outcome using content analysis of the Bangladesh government and media, the international media and the views of the scholastic community. The Bangladesh government and media underlined the natural origins of the disaster, worsened by the irrational behaviour of individuals and the limited resources of the nation. There was also a move to try to link the cyclone to global warming and the greenhouse gas emissions of industrialised countries. Non-Bangladeshi accounts tended to focus instead on the poverty of the individuals, and the structural inequality of 
society, which compels people to live in hazardous areas (Dove and Khan, 1995, p. 445). However, the view of the authors of this paper, and also that implicit in recent policy agendas, such as the Hyogo Framework (UNISDR, 2005), is that multiple 'vulnerabilities' can often be counteracted by the resilience and adaptive capacity of active survivors.

Ohiduzzaman (1993) points to the severity of cyclones, a lack of cautiousness and an improper disaster management system as the main determining factors delineating the extent of cyclone damage. In addition, people resist moving to the cyclone shelters during an event. The reasons are thought to be disbelief of warnings among coastal dwellers, the utilisation of incorrect methods in the warning system, the distance of cyclone shelters from settlements, mismanagement of weather forecasts and a lack of proper management of the cyclone shelters (Haider, 1992; Ahsan and Eusuf, 1994). For effective employment and management of cyclone shelters, multi-purpose versions have been built in carefully selected locations, identifying uses for both normal and disaster periods (BUET and BIDS, 1993; Nizamuddin, 1997). Two versions of multi-purpose shelters are shown in Figure 1. Their use during non-disaster periods demonstrates an excellent dual disaster and development function. However, the underlying causes of non-use of shelters have not always been fully identified. One element of the present study was to try to understand the behaviour of the coastal people during cyclone hazard periods, including why they are not able to reach the shelter centre in time. Figure 2 shows the typical lack of protection for households close to a coastal margin. Some defence is provided by an artificial embankment (a), but this is not sufficient to protect the spread of housing in this zone. In many areas, there is no embankment. Furthermore, mangroves that offered some shelter have been removed to make way for shrimp- and salt-farming enterprises (b). Such levels of direct exposure to cyclone hazards mean that the shelters are all the more crucial as an intervention, as one of a few ways in which people can gain protection.

\section{FIGURE 1 NEAR HEAR}

Source: authors (Figure 1a also appears in Collins, 2009b).

\section{FIGURE 2 NEAR HEAR}

Source: authors.

Hoque et al. (1993) studied environmental health using a quantitative questionnaire survey after the 1991 cyclone that targeted affected people and health personnel. Water and sanitation problems were identified as two major problems, with a lack of environmental health knowledge observed among affected people and the health service providers. A study by Rahman and Bennish (1993) indicated that health relief and rehabilitation after the 1991 
cyclone were appropriate and effective. As such, despite limitations, it was possible to control the spread of communicable diseases and mortality post cyclone.

Women and children are more vulnerable to cyclones for various reasons. Women's willingness to leave their homes, a mother's protective instinct (being prepared to die trying to save her children), and the saree (women's clothing) and long hair of Bangladeshi women (hindering movement while trying to swim in tidal waves) have all been cited as reasons (CARE, 1991; CARITAS, 1991; Haque and Blair, 1992; Ohiduzzaman, 1993). However, more structural issues that impinge on culture, rights and representation have also been highlighted, and it is increasingly well recognised that disasters can impact differentially on people depending on their age, caste and class, gender and social status (Ikeda, 1995). Preparedness for disaster requires decision-making and leadership. Women are generally excluded from such roles in this region. Hence, various non-governmental organisations (NGOs) have included gender aspects of rights and representation in their campaigns as a risk reduction approach. This is being encouraged by the international community, including through United Nations (UN) agencies, but it is not yet clear as to the extent to which the matter is actually addressed from within communities. The social determinants of increased vulnerability are central to this paper, recognising that they occur in a changing context and relative to the capacity of local people to negotiate hazards, rights and freedoms.

Ali (2006) has examined the climatology of cyclones in the Bay of Bengal for the past 110 years, as well as trends in cyclone frequency and intensity. There is evidence that the coastal inhabitants depend on indigenous early warning indicators of cyclone hazard based on an observation of unusual weather, sea patterns and animal behaviour (Hassan, 2000; Alam et al. 2003; Howell, 2003). Alam (2002, 2003) analysed and differentiated the postcyclone adjustment process on Sandwip Island by dividing it into three hazard risk zones on the basis of the surge height of the 1991 cyclone: badly affected areas (BAA); moderately affected areas (MAA); and less affected areas (LAA). ${ }^{1}$ The study showed that during reliefrehabilitation stages, external agencies were found not to understand exact requirements in the three hazard risk zones (Alam, 2002, 2003). Different NGOs took part in relief and rehabilitation programmes in the post-cyclone period, highlighting their activities in different books, papers and manuals (CARE, 1991; CCDB, 1991; BRAC, 1991; ADAB, 1992). There remains, however, a conspicuous absence of research into the whole context of vulnerability and local coping with cyclone hazards. The study described in this paper attempted to address this issue through participant observations, field surveys and discussions with members of affected offshore islands and with mainland coastal communities in Bangladesh. The assumption is that one requires an in-depth understanding of the affected community in 
order to comprehend the underlying causes of vulnerability and local responses to cyclone disasters.

\section{Aims and objectives of the study in coastal and island Bangladesh}

The research reported here aimed to identify the contexts within which people are vulnerable to cyclone hazards and consequent local responses to living with cyclone disasters in the coastal zone of Bangladesh. More specifically, it sought:

- to examine the origins of vulnerability to cyclone hazards given local people's experiences on the Bangladesh coast; and

- to identify adaptation strategies and coping before, during and after cyclone disasters in the light of local people's past experiences.

\section{Methods}

Qualitative approaches, such as in-depth interviews and observations, are useful tools for understanding people's responses to and the impact of a disaster (Mileti, 1987; Quarantelli, 2002). The field research compared a combination of participant observations and nonparticipant external interactions with coastal communities. During the April 1991 cyclone, Edris Alam (the first author of this paper) was 15 years old and residing on Sandwip Island. Witnessing the catastrophic event from a distance of some five kilometres in the Bay of Bengal provided an opportunity to observe island communities' cyclone hazard response processes pre, during and post cyclone. This qualitative and personalised data reflection has significance; Lofland and Lofland (1995) refer to it in the sense of being able to use the roles of others in order to acquire social knowledge. Although Edris Alam left Sandwip Island in 1991 to further his education in Chittagong City and subsequently Dhaka City in Bangladesh, he visited his village house on the island at least twice a year up to 2008 . He also travelled back to this location shortly after Cyclone Sidr struck in November 2007. During his visits, he took notes on local people's lives and means of livelihood, their attitudes to cyclone hazards and their coping strategies. Andrew Collins (the second author of this paper) has visited Bangladesh frequently since 1999 as well as other parts of the world following coastal disasters. Edris Alam's observations and experiences of cyclone hazards have in this instance helped with analysing the opinions of Bangladesh coastal and island communities. Some of these were verified earlier through questionnaire surveys and focus-group discussions (FGDs).

Four study areas were selected for this research from within the cyclone risk zone ${ }^{2}$ in coastal areas of Bangladesh. Of the study sites, Chakoria is located on the mainland coast, Kutubdia 
Island is on the near-shore of the Chakoria coast, Sandwip is an offshore island in the Bay of Bengal, and Urir Char is an isolated area located off the northern part of Sandwip (see Figure 3). Chakoria and Kutubdia lie within Cox's Bazar district, ${ }^{3}$ while Sandwip and Urir Char lie within Chittagong district. Located on the eastern part of the Bay of Bengal, these two districts are in the most cyclone hazard-prone areas of Bangladesh (BUET and BIDS, 1993). Chakoria, Kutubdia and Sandwip are thanas—administrative units in Bangladesh—whereas the selected area of Urir Char is a union within Sandwip thana. Agriculture and fishing are the two major occupations in these coastal areas of the country. The houses are constructed primarily of straw, bamboo and corrugated iron sheets (BBS, 2001).

\section{FIGURE 3 NEAR HERE}

Source: authors

Apart from Edris Alam's life experiences of cyclone hazards up to 1991, participant observations and subsequent visits to the coastal areas, a combination of semi-structured and open-ended questionnaire surveys and FGDs were conducted to collect data over a three-month period. Before administering the questionnaire survey, a list of households from the selected study areas was prepared. Selection of these households was based on the provision that household heads would be available for interview. From the selected household list, 120 semi-structured and open-ended questionnaires were administered randomly among household heads aged more than 45 years who had multiple severe cyclone experiences and who were living within five kilometres of the Bay of Bengal. Household heads were interviewed as they have a good sense of the household's vulnerability to threats, such as cyclones, being in most instances responsible for their security and livelihoods. Earlier studies in this area indicate that people living within this distance of the Bay of Bengal suffered most in previous cyclones (Alam et al., 2003). Of the 120 household heads interviewed, 108 were male and 12 were female. This reflects the fact that a woman rarely heads a household in Bangladesh. Furthermore, it is acknowledged that because the interviewers were male, this introduced some limitations with regard to interviewing conservative female-headed households. Other studies associated with the authors use female interviewers to sample specifically female respondents. However, in this instance, headship of a household was the main criterion, such that despite gender differentials in the sample, valuable information from households was acquired.

The respondents had experience of the cyclones of 1970, 1985, 1991, 1997, 1998 and 2007 that devastated the coastal and islands areas of Bangladesh. Respondents of more than 45 years of age were chosen for individual interviews and to participate in FGDs because it was 
thought that they could better explain the causes of vulnerability and coping, in view of their multiple cyclone experiences. These respondents were members of farming and fishing communities in this coastal belt. The questionnaire included questions on the reasons for vulnerability to cyclone hazards in terms of previous cyclone losses, long-term adaptation strategies, and pre-, during- and post-cyclone responses, following the formation of a great depression in the Bay of Bengal. The pre-cyclone period has been defined as the phase after the formation of a great depression until the coastal area is struck by a cyclone-associated sea surge. The during-cyclone period is the time span of the cyclonic water surge on the land. For this study, the post-cyclone period is defined as the stage after the recession of the sea surge from the land until relief and rehabilitation support is received.

In addition to the 120 semi-structured and open-ended questionnaires, eight FGDs across study sites were held with the coastal and island inhabitants of more than 45 years of age at a convenient time and place for them. Of the eight FDGs, four were conducted among male heads of the agricultural communities, two among male heads of the fishing communities, and two among female members of each of the agricultural and fishing communities. Six participants were present during each discussion. The coastal and island people were found to have overwhelming memories of their past cyclone experiences. Basic accounts thus helped to generate clear insights on the vulnerability context, hazard responses, and coping with cyclone disasters. These results were contrasted with existing theoretical and development ideas from mixed secondary sources alluded to earlier in this paper.

\section{Findings and analyses: exploring vulnerability and local responses}

Vulnerability due to location and pattern of settlement

Overall, the findings of this study indicate that location and pattern of settlement are the most important factors determining people's vulnerability to a tropical cyclone on the Bangladesh coast. This view of the coastal people is supported by the experience of Edris Alam, who lived through the 29 April 1991 cyclone. Although there were no casualties among his immediate neighbours, the following morning he saw corpses by the roadside, transported from the furthest coastal areas by sea surge. On 30 April 1991, he travelled to the coastal zone to witness the devastation that the cyclone had produced on the previous night. There, he observed a higher density of corpses than in his neighbourhood, mostly females and children.

Coastal and island people frequently differentiated vulnerability to previous cyclones by form of settlement, such as Puran Bari ${ }^{4}$ (old settlement), Natun Bari (new settlement), Baro Bari (large settlement) and Choto Bari (single settlement). Most of the past devastation occurred 
in single and new settlements. Manik, a farmer from Kutubdia Island, suggested that the people who lived in scattered settlements near to the coast and in linear settlements along the coastal embankment were those who died in the April 1991 cyclone. This type of settlement is more susceptible to cyclonic sea surge. Unfortunately, this type of settlement is currently spreading due to family fragmentation and to what the older population regards as individualism in this area.

Houses on the inner part of the island and coastal areas are compact in nature, consisting on average of six or seven houses called Baris with dense tropical forest surroundings. Several closely located Baris make up a Samaj. ${ }^{5}$ This type of settlement is less susceptible to severe cyclonic wind and the later sea surge. Houses closer to the coast are scattered, newly formed, and of various types. The soil of the new settlement was not strong enough and, in most cases, the land was without trees or had very small trees. During previous cyclones, this settlement faced more severe wind speeds and the first onslaught of sea surge caused devastation within a few minutes. The linear settlements along the coastal and island embankment consist of straw, bamboo houses. Apart from wind speed and sea surge, they are also vulnerable due to fragmentation of the embankment in major cyclone periods.

\section{Vulnerability due to inappropriate land management systems}

The coastal and island denizens (occupants) living along the embankment in Chakoria, Kutubdia and Sandwip are landless and have lost their homes three times on average due to coastal erosion. As the Government of Bangladesh built and is responsible for maintaining the coastal embankment, the landless people construct settlements easily along this public embankment space. The number of landless was more in Urir Char and they have shifted their homes five or six times during their lifetime. Local people indicated that, during the early 1980s, approximately 740 households left Sandwip to settle in Urir Char. All of them were landless in Sandwip and formed isolated settlements in Urir Char. The present isolated settlements on this small island have therefore produced another aspect of vulnerability to cyclone disasters through the government's land management system. With the enactment of the 1984 Land Reform Ordinance, the Office of the Deputy Commissioner (the head of district-level administration) finally approved all allocation and settlement matters, following a series of procedural steps. After the act came into force, the Government of Bangladesh allowed the landless people ${ }^{6}$ two acres of land each, for agricultural and settlement purposes. These poor people individually made homes in the middle of an allocated plot. The whole island thus formed as a scattered settlement. However, some poor settlers are still not able to occupy their land beyond their house. A significant number of people reported that they remain landless in the Char area. They also alleged that rich and politically influential 
persons from Sandwip Island own the majority of land in the Char area due to their close relations with land registration officials. They lease their vulnerable lands to landless Char denizens in exchange for cash, or they take a share of the agricultural production of these lands.

\section{Vulnerability due to means of livelihood and a lack of infrastructure}

The main occupations of the coastal and island communities are agriculture and fishing in the Bay of Bengal. During the peak cyclonic period (April-May and October-November), farmers are used to working in their fields and fisherman in the Bay of Bengal. The questionnaire surveys and discussions indicate that every year, the coastal and island people experience several tropical cyclones. It is tough for them to leave their means of livelihood and belongings when they hear of or comprehend the formation of a cyclone hazard in the Bay of Bengal. In this regard, a comment by Kalam, a 42-year-old farmer near the coast of Sandwip Island, is of interest:

I used to see every year cyclones in this area but I do not know which cyclone would be dangerous. I always work in my paddy field. I sometimes hired day labourer to work in my field and I have to pay for them. I need their services in exchange. Therefore, I cannot leave working just on hearing a warning signal. I am responsible for earning livelihoods of my wife, four children and my aged parents. I rear two cows for ploughing my crops. I have to look to see whether my cows are enough fed, for better services tomorrow. There is no cyclone shelter nearby to my houses for us or a raised place for shelter of my domestic animals. I rather rely on Allah's wish, whatever I have got in my fate, I believe that will happen in my life.

The lack of a proper transport infrastructure is another important factor in people's vulnerability to cyclone disasters. Cyclone hazard is associated with severe wind and rain. Yet, most of the roads in the near coastal areas are made of earth. Most earth-made boundaries of the crop field are used to travel to the main road, which is also sometimes built of mud. During the rainy season or cyclonic period, these passageways are damaged or destroyed. Insufficient cyclone shelters in the most hazard-prone areas means that a decision to move to distant and hard-to-reach cyclone shelters becomes a matter of making one's livelihood vulnerable during the extended period of disruption.

\section{Vulnerability due to late responses to warnings and a complex decision-making process}

The coastal and island people's particular process of response to cyclone can make them vulnerable to disaster. As they are used to facing multiple hazards each year, their responses to warnings depend on the intensity of wind speed, experience of hazards, local 
belief in the probability of dangerous cyclone events, or the presence of a cyclone signal hoisted by the Bangladesh Meteorological Department (BMD). If the symptoms of previous hazards coincide with a BMD warning of about six to seven on average, they start to prepare to save belongings or decide to leave their homes for a cyclone shelter or other stronger buildings nearby. Before that, they adopt a 'wait-and-see' approach, observing whether the cyclone intensity is rising. During fieldwork in southwest, coastal Bangladesh after Cyclone Sidr on 15 November 2007, the affected people were found to have been reluctant to respond to cyclone warnings, even when the warning signal was raised to 10 for them. This was because they had not experienced a similar major cyclone since 1970. During Cyclone Sidr, most of the affected households only left their houses when they saw water coming close. Discussions with a female group indicated that the decision to save belongings and to leave home in most cases rests with the male head of the household. Therefore, the other family members wait for the arrival of the family head from outside. Due to conservative religious beliefs, many of the male heads of households prefer not to move to cyclone shelters, thinking that the female members of household might lose their purdha (a scarf worn by Muslim women on their heads) while travelling to or staying at cyclone shelters. The household also considers the problems that can arise at cyclone shelters, such as space issues, lack of light and poor sanitation.

Due to affection for domestic animals in these communities, concern about belongings in general, and loss of their only means of livelihood, household heads do not opt to move to cyclone shelters easily. However, if the severity of the cyclone increases and warning signals mount, the family may then decide to go. By then, though, they may not be able to move because the wind and rainfall have increased. Besides the elements, trees uprooted by the wind can block the access road to the cyclone shelters. A combination of rain and wind may damage or destroy earthen roads. Fear of injury by flying debris is another factor that deters people from moving to cyclone shelters once the winds gather pace. While the list is by no means exhaustive, Table 1 summarises some of the contexts of vulnerability encountered in this study.

Table 1 Vulnerability context of cyclone disasters on the Bangladesh coast

\begin{tabular}{|l|l|}
\hline Vulnerability context & Source of information \\
\hline $\begin{array}{l}\text { Isolated and scattered settlement layout, and settlements along the } \\
\text { embankment. }\end{array}$ & Questionnaire surveys and FGDs \\
\hline Lack of sufficient cyclone shelters. & Questionnaire surveys and FGDs \\
\hline Lack of adequate transportation to move to cyclone shelters during & Participant observation, questionnaire \\
\hline
\end{tabular}




\begin{tabular}{|c|c|}
\hline cyclonic period. & surveys and FGDs \\
\hline Lack of alternative skills other than fishing and agriculture. & FGDs, secondary sources \\
\hline Rapid spread of unprotected settlements in hazardous places. & Participant observation \\
\hline $\begin{array}{l}\text { Vulnerability of females, children and older people. Female's long } \\
\text { hair and special clothing hinder swimming in a cyclonic surge. }\end{array}$ & $\begin{array}{l}\text { Participant observations and FGDs with } \\
\text { females }\end{array}$ \\
\hline $\begin{array}{l}\text { Lack of decision-making power among female members of } \\
\text { household. }\end{array}$ & Woman's FGD \\
\hline Late responses to cyclone warning. & Participant observations and FGDs \\
\hline Excessive love of/devotion to property and animals. & FGDs with agricultural community \\
\hline Poor people's debt to money lenders. & FGDs with fishing community \\
\hline Inefficient administrative system. & Secondary sources, key informants \\
\hline Increases in unprotected settlements in hazardous places. & $\begin{array}{l}\text { Personalised respondent accounts, } \\
\text { frequent field visits and participant } \\
\text { observation }\end{array}$ \\
\hline Lack of proper land use management in high cyclone risk areas. & $\begin{array}{l}\text { Personalised respondent accounts, field } \\
\text { visits and secondary sources }\end{array}$ \\
\hline Lack of specific housing policy for settling in high cyclone risk areas. & $\begin{array}{l}\text { Personalised respondent accounts, field } \\
\text { visits and secondary sources }\end{array}$ \\
\hline $\begin{array}{l}\text { Lack of social networks in at-risk places due to new scattered and } \\
\text { isolated settlement. }\end{array}$ & $\begin{array}{l}\text { Field visits, questionnaire surveys and } \\
\text { FGDs }\end{array}$ \\
\hline Fishing in peak cyclonic season in the Bay of Bengal. & $\begin{array}{l}\text { Field visits and FGDs with agricultural } \\
\text { community }\end{array}$ \\
\hline Agricultural activities in areas at risk of cyclones. & $\begin{array}{l}\text { Field visits and FGDs with agricultural } \\
\text { community }\end{array}$ \\
\hline Lack of awareness of scientific basis of cyclone hazards. & $\begin{array}{l}\text { Frequent visits, questionnaire surveys } \\
\text { and FGDs }\end{array}$ \\
\hline
\end{tabular}

Note: participant observation includes Edris Alam's personal experience of surviving cyclones in the region.

\section{Local responses: long-term adaptation through house design and tree planting}

Long-term adaptation techniques are employed in response to past cyclonic hazard experiences. For example, house construction can partly take into account excessive rain during the monsoon season as well as cyclonic sea surge and wind that destroy some of the coastal embankment every year. Each year, on average, between five and six kilometres of the outer limit of Sandwip Island and Kutubdia and between two and three kilometres of the Chakoria coastal area are inundated by cyclone associated sea surge or high tide from the Bay of Bengal. The coastal and island people there have raised the height of the plinthlocally called bithi-of their houses using mud. One can observe differences in plinth height 
on the island and in mainland areas. The height of the plinth in coastal Chakoria is about five feet and on Sandwip and Kutubdia Island it is around six feet above cropland. If the plinth is high enough, house owners are more likely to save family members and belongings from severe tidal surges.

The inhabitants of Urir Char have raised the height of the plinths on average to around eight feet above the level of cropland. There is no embankment securing the Urir Char area, so every year during the monsoon season, the tidal surge from the Bay of Bengal submerges the entire island. Rafiqul Islam, a farmer from south Urir Char, enhanced his protection by raising the plinth of houses approximately 10 feet in order to save his seed store and valuable property from abnormal tidewater during the monsoon season. Interview respondents also reported that their thatched-roof houses would act as lifesaving shelters during a great cyclonic surge. Creating a plantation of trees around the homestead is another important adaptation technique for saving life, houses and properties in wind and sea surges. The coastal and island people suggested that, usually, they prefer to plant big-branched trees around the homestead, as they are more effective.

\section{Local responses: pre cyclone}

When coastal and island people in these areas were asked what they did when they realised a cyclone was imminent, they often replied that, if the danger signal number is more than six and enough indigenous signs are present (Hassan, 2000; Alam et al., 2003; Howell, 2003), they generally increase religious activities to satisfy Allah/lshwar (God). They view extreme environmental events as 'the wraths of nature' or as Allah's gazab, the wrath of God that befalls persons who or communities that have sinned. Different religious communities worship in different ways in order to resist the cyclone. The Hindu community offers sugar, coconut and banana to the seawater. Muslims practise religious obedience in mosques during prayer times. In madrassas ${ }^{7}$ (religious Muslim schools), religious teachers compel students to stay longer to pray loudly for Allah to resist the cyclone. All of these religious activities are performed in the firm belief that only Allah can prevent the cyclone.

As well as praying to Allah, a majority of respondents reported that, prior to a cyclone, they take several steps to reduce their losses and to save their belongings. Their preparation depends on the presence of local signs (indigenous early warning) and the cyclone signal hoisted by the BMD. Some coastal and island people hide their food, valuables and money in the earth. Other respondents were found to be apathetic about preparation. Some coastal people send their valuable materials to their relatives in safer areas. Some habitants of the near coastal area also sought shelter in their relative's homes located in the inner areas. 
Social leaders, known as matbor, try to visit the residents of the area to observe whether everyone is engaging in the necessary preparation for the approaching hazard. Households implement several measures to protect houses if they are not made of brick. They tie their houses to surrounding big trees, if available, using strong rope. They also insert new poles around the house, sinking them into deep holes. Thekas-setting new poles diagonally around the house-is another common technique used to save houses. Before a cyclone, farmers are known to consider the safety of domestic animals as seriously as that of family members. If the warning signal number hoisted is nine or more, they set domestic animals free from sheds to allow them to survive the surge water. They also try to send domestic animals to highland areas. The questionnaire surveys and participant observations revealed that farmers also try to collect agricultural crops from the field before an approaching cyclone hazard.

\section{Local people's survival strategies during the cyclonic surge}

Just prior to the arrival of a cyclone surge, coastal and island occupants are often still trying to reach the cyclone shelters, higher places and other strong buildings. Those coastal people not able to reach cyclone shelters frequently take refuge on rooftops during the water surge. They have been observed helping each other irrespective of social class. Local young community members play an important role in saving the lives of women, children and older people during the water surge. Young men in these communities are known to fall victim due to their attempts to save the lives of family members. However, there is evidence that, overall, more women die in cyclone and flash-flood events than men. This is due to many of the reasons noted earlier-more in-depth work on the gender dynamics of these emergencies continues. During the 1991 cyclone surge, many people saved their lives by staying on the roofs of their thatched homes. Typically, they use harrow to climb on to the roofs of their homes and blankets to protect themselves from cyclone-induced hailstorms during sea surge periods. The big branches of trees become life-saving shelters for many people and domestic animals. Remaining on floating logs during surge periods saves the lives of some people. Moreover, the co-existence of humans, animals and wild species, such as snakes, has been observed in cyclone shelters, houses, and large trees during cyclone surges.

\section{People's coping strategies post cyclone}

After the recession of cyclone surge water, different occupational groups respond in different ways to the devastating situation. The survivors first go out in search of their family members. Then, they focus on seeking out a means of survival and livelihood. The fishermen search for their nets and boats and the farmers for their cattle. Young girls and children 
collect floating food and pick up fruit from in and around their houses. It can take four or five days for the relief programme to reach the devastated areas. This is despite the best efforts of well-meaning emergency programmes operating in difficult geographical locations in cyclone-affected areas of Bangladesh. Unaffected local people, however, offer assistance to affected people. In addition, during this post-cyclone period, people take whatever food is available to them, such as wetted rice, bread, sweet potato, pumpkin, green banana, coconut and mango. Some of these fruits are transported from crop fields by surge water. Green coconut seemed to be the only source of drinking water available for several days immediately after the cyclone event. Adolescent girls tend to be given the important role of collecting water from long distances. In rural villages of Bangladesh, where women's activities are confined to within the household, exceptions are made during a disaster period to permit women to engage more openly in daily living activities.

Those interviewed indicated that they wear the same saree (in the case of a woman) and lungi (in the case of a man) for several months after the cyclone because most of their clothes are lost during the surge period. At this time, wealthy relatives and neighbours donate clothing to poorer victims. This was further evidenced in the case of Cyclone Sidr, after which organisations and individuals from around Bangladesh immediately sent contributions in the form of relief to the focal point of the disaster. After a devastating cyclone, the people within the coastal and island areas tend to be friendlier and to extend all sorts of cooperation to one another. However, despite evidence of goodwill, institutional assistance to the most vulnerable people can be infrequent due to disruption of transportation from administrative centres. Finance institutions have been known to write off debt owed through micro-credit schemes in the case of the most-affected people. Reliance on traditional localised social networking and kinship for assistance during emergencies is necessary and prevalent. People living in unaffected areas of Sandwip Island provide food assistance to the affected people. Many coastal dwellers take shelter in their relative's homes if these have escaped the surge. There are accounts of the samaj remaining operational in the post-disaster period, contributing physical and financial aid, food and other material support.

Although the fishing community usually works only in the fishing sector, its members assist in difficult periods by cleaning and repairing houses within the Muslim community. They also manage to catch fish by hand using small nets and locally-made fishing traps. Women members of the fishing community also work as maidservants in other houses to earn daily meals. Thus, the occupation of a fisherman changes a lot during these periods. In normal times, fishermen go fishing separately, but after a cyclone, they work as a group and share 
the same net and boat. The farmers have to collect drinkable water for their surviving cattle. Banana trees get used as feed for cattle for several days after a cyclone. In this period, they rent out their cattle for ploughing crop fields in exchange for food for their cattle. After a cyclone, farmers cultivate again and usually harvest a bumper crop from the resultant deposited alluvial soil.

After a devastating cyclone, the top priority of survivors is to rebuild their homes and to search for house materials to replace those removed by violent winds and surge water. On an emergency basis, the victim constructs a special manchan (tent, a type of temporary house) using whatever materials are available. Cuts, diarrhoea, dizziness, dysentery, fever, nausea and shivers are widespread in the post-cyclone period. People primarily use leaves, local herbal remedies and other treatments to address these health problems. A further study of the Disaster and Development Centre at Northumbria University, supported by the United Kingdom's Economic and Social Research Council (ESRC), is establishing the manner in which prior disaster health security helps to generate overall resilience to disasters based on the ground realities of these contexts (Ray-Bennett et al., 2010), including through self-care (Edgeworth and Collins, 2006) - the study has implications for people-centred early warning (Collins, 2009a). While by no means exhaustive, Table 2 summarises some of the context of adaptation and coping strategies in the pre-, during- and post-cyclone periods, as revealed to date through the work supporting this paper.

Table 2 Adaptation and coping strategies associated with cyclone periods

\begin{tabular}{|l|l|}
\hline Adaptation strategies & Sources of information \\
\hline Activities, preparation and coping strategies (pre cyclone) & $\begin{array}{l}\text { Field visits, questionnaire surveys and } \\
\text { FGDs }\end{array}$ \\
\hline Raising the height of the plinth. & Questionnaire surveys and FGDs \\
\hline Planting big-branched trees around the homestead. & $\begin{array}{l}\text { Personalised respondent accounts, } \\
\text { participant observation, questionnaire } \\
\text { surveys }\end{array}$ \\
\hline Increasing religious activities. & Participant observation and FGDs \\
\hline Gathering crops from fields. & $\begin{array}{l}\text { Personalised respondent accounts and } \\
\text { participant observation }\end{array}$ \\
\hline Hiding food and valuables in the earth. & Questionnaire surveys and FGDs \\
\hline $\begin{array}{l}\text { Visits from social leaders to raise awareness of necessary } \\
\text { preparations for the approaching cyclone hazard. }\end{array}$ & Questionnaire surveys and FGDs \\
\hline Setting new poles diagonally around the house.
\end{tabular}




\begin{tabular}{|c|c|}
\hline $\begin{array}{l}\text { Setting domestic animals free from sheds to allow them to survive } \\
\text { surge water. }\end{array}$ & $\begin{array}{l}\text { Participant observation, questionnaire } \\
\text { surveys and FGDs }\end{array}$ \\
\hline Endeavouring to reach cyclone shelters and other safe places. & $\begin{array}{l}\text { Participant observation, questionnaire } \\
\text { surveys and FGDs }\end{array}$ \\
\hline \multicolumn{2}{|l|}{ Survival and coping strategies (during cyclone) } \\
\hline $\begin{array}{l}\text { Defining the role of the local youth with regard to saving the lives of } \\
\text { children, women and older people during surge water. }\end{array}$ & Participant observation \\
\hline Using cyclone shelters. & Questionnaire surveys and FGDs \\
\hline $\begin{array}{l}\text { Co-existence of humans, animals and wild species in different } \\
\text { places throughout cyclonic surge. }\end{array}$ & Questionnaire surveys and FGDs \\
\hline \multicolumn{2}{|l|}{ Coping strategies (Post cyclone) } \\
\hline $\begin{array}{l}\text { Searching for kith and kin and looking for housing utensils and } \\
\text { means of livelihood. }\end{array}$ & Participant observation and FGDs \\
\hline $\begin{array}{l}\text { Active participation of all age groups in coping with devastation, } \\
\text { including those family members who do not normally work. }\end{array}$ & Participant observation \\
\hline Making waste food available before help arrives from outside. & Questionnaire surveys and FGDs \\
\hline $\begin{array}{l}\text { Building a special tent-type of shed for those who have lost their } \\
\text { houses. }\end{array}$ & $\begin{array}{l}\text { Participant observation, questionnaire } \\
\text { surveys and FGDs }\end{array}$ \\
\hline Community cooking using a group oven for several days. & Participant observation and FGDs \\
\hline $\begin{array}{l}\text { Allowing women to become more active in the outside world in order } \\
\text { to help cope with the devastation. }\end{array}$ & $\begin{array}{l}\text { Participation observation and FGDs } \\
\text { with females }\end{array}$ \\
\hline $\begin{array}{l}\text { Assistance of local social networks and groups of relatives for those } \\
\text { who are in disadvantaged positions. }\end{array}$ & $\begin{array}{l}\text { Participant observation, questionnaire } \\
\text { surveys and FGDs }\end{array}$ \\
\hline $\begin{array}{l}\text { Support from relatives and social network residing outside of the } \\
\text { affected areas of Bangladesh and in foreign countries. }\end{array}$ & $\begin{array}{l}\text { Participant observation, questionnaire } \\
\text { surveys and FGDs }\end{array}$ \\
\hline
\end{tabular}

\section{Discussion and conclusions}

Human fatalities arising from cyclone hazards in the coastal areas of Bangladesh have occurred mostly in the near coast and isolated settlements. This finding has importance for formulating cyclone disaster mitigation policies, particularly in locating cyclone shelters. Based on impressions derived from participant observations, field surveys and FGDs, the findings highlight three underlying vulnerabilities to cyclone disasters: hazard risk perceptions; pre-cyclone decisions whether to go to cyclone shelters; and inadequate land management policies in the coastal areas of the country. These findings also reflect some of the wider comments from disaster- and development-related studies that increasingly emphasise the longstanding awareness that strategies must be community-based. A variety of authors are currently making this point. For example, Hilhorst and Bankoff (2004) note how vulnerability is also about people, their perceptions, ideas about risk, and practices in 
relation to disaster. Questions surround the nature of resilient societies following its promotion through the Hyogo Accord of 2005 (Paton and Johnston, 2006; Birkmann, 2006). Meanwhile, ongoing studies are providing case material on community-based risk and resilience committees established in various parts of the world. ${ }^{8}$ The goal is to try to find ways of avoiding inappropriate disaster governance, which is well known to make people vulnerable (Anderson, 1999; Hilhorst, 2004). Collins (2009b) provides a version of disaster and development studies that synthesises much of the people-centred perspectives flagged here.

The example of the cyclone-prone areas of Bangladesh demonstrates that land management processes encourage poor people to form scattered settlements in hazardous places without adequate forms of protection. Scattered settlements are vulnerable to the flooding that submerges most of the floodplain of Bangladesh every year (Mallick, 2007). Vulnerability is greater among people in isolated and scattered settlements because of increased exclusion from information aimed at improving preparedness, disrupted traditional social networks and insufficient survival shelters to protect against sea surge. While activities in hazardous places have exacerbated women's vulnerability by reducing their access to strategic response, it is felt that the influences of local culture, behaviour and coping are far more complex than is immediately apparent. There is evidence of support for the development of broader and more comprehensive vulnerability and resilience analyses. At a local level, these must attempt to move beyond hazard-centred or theoretically 'decided' approaches underscored in oft-cited studies of the discipline (such as White, 1974; Blaikie et al., 1994; Cannon, 1994; Hewitt, 1997), although these continue to contribute.

In relation to coastal Bangladesh and people's vulnerability to cyclone hazard, we draw attention to the role of unplanned settlements, dependency on livelihoods in dangerous places, the lack of a nearby refuge (reflected by distance to cyclone shelters) and problematic transportation. However, these factors manifest themselves alongside other cognitive variables governing hazard response processes pre cyclone, and are further moderated by gender and other local cultural factors. The coastal and island people generally increase their religious activities prior to a cyclone to satisfy their God. In this regard, further and alternative awareness can be generated among coastal communities of the nature of cyclones, such as by revealing at a local level the satellite imagery that detects cyclones. Transport networks between settlements and cyclone shelters could also be improved to facilitate the movement of people and goods during disaster events. 
The coastal and offshore inhabitants of areas near the Bay of Bengal often become isolated during cyclones, yet they cope with these events due to knowledge passed down by previous generations. Although people passively react to cyclone hazards before the event, during and after the cyclone and associated sea surge they demonstrate a strong coping mechanism, including ensuring the survival of daily necessities through individual initiatives, kinship ties and obligations, and social networking. These instinctive survival strategies during and after a cyclone have existed for generations and play a significant role in people's ability to survive disasters in coastal areas of Bangladesh. Although this paper does not evaluate the actions of aid agencies, the implications for these institutions are that much local knowledge and capacity exists in these communities and can be incorporated in efforts to target disaster prevention and response. ${ }^{9}$

\section{Correspondence}

Andrew Collins, Disaster and Development Centre, School of Applied Sciences, Northumbria University, Newcastle-upon-Tyne, NE1 8ST, United Kingdom. E-mail:

andrew.collins@northumbria.ac.uk

\section{References}

ADAB (Association of Development Agencies in Bangladesh) (1992) The 1991 Apocalypse role of NGOs in emergency cyclone relief. ADAB, Dhaka.

Ahsan, R.M. and A.Z. Eusuf (1994) 'Determinants of spatial and gender differences in coastal cyclone shelter use in Island and Mainland Areas in Cox'sBazar'. Oriental Geographer. 38 (1 and 2). pp. 44-58.

Alam, E. (2002) Post cyclone adjustment Process: The case of Sandwip, Bangladesh. Unpublished MSc Thesis, Department of Geography and Environment, University of Dhaka, Bangladesh.

Alam, M.E. (2003) 'Post cyclone adjustment process: basic needs perspective'. Oriental Geographer. 47(2). pp. 47-60.

Alam, E., Bhuiyan, R.H. and Akbar, M.T.(2003) 'Cyclone disaster in coastal Bangladesh: local knowledge and indigenous coping strategies'. Bhugal Patrika (A Journal of Geography). 22. pp. $124-133$. 
Ali, A. (2006) 'Vulnerability of Bangladesh to climate change and sea level rise through tropical cyclones and storm surges'. Water, Air and Soil Pollution. 92(1 and 2). pp. 171-179.

Anderson, M.B. (1999) Do No Harm: How Aid can Support Peace - or War?Lynne Rienner, London.

BBS (Bangladesh Bureau of Statistics) (2001) Bangladesh Population Census-2001. Government of Bangladesh, Dhaka.

Birkmann, J. (ed.) (2006) Measuring Vulnerability to Natural Hazards: Towards Disaster Resilient Societies. United Nations University Press, Bonn.

Blaikie, P., T. Cannon, I. Davis, and B. Wisner (1994) At Risk: Natural Hazards, People's Vulnerability and Disasters. Routledge, London.

BRAC (Bangladesh Rural Advancement Committee) (1991) Cyclone 1991: what people knew and did. BRAC, Dhaka.

BUET (Bangladesh University of Engineering and Technology) and BIDS (Bangladesh Institute of Development Studies) (1993) Multipurpose Cyclone Shelter Program: Report Prepared for the Planning Commission of Bangladesh. United Nations Development Program/World Bank/Government of Bangladesh project BGD/91/025.

Burton, I., R.W. Kates and G.F. White (1993) The Environment as Hazard. Second edition. The Guilford Press, New York, NY.

Cannon, T. (1994) 'Vulnerability analysis and explanation of natural disasters'. In A. Varley (ed) Disasters, Development and Environment. Wiley, Chichester. pp. 13-30.

CARE (Cooperation for American Relief Everywhere) (1991) After the Storm: Bangladeshi Response to the Cyclone. CARE-Bangladesh, Dhaka.

CARITAS (1991) Cyclone-91: In memorial. Caritas-Bangladesh, Dhaka.

CCDB (Christian Association for Development in Bangladesh) (1991) CCDB Responds to April 29 Cyclone and Other Disaster. CCDB, Dhaka. 
Chambers, R. (1983) Rural Development: Putting the Last First. Longman, London.

Choudhury, A.M. (1998) 'Disaster monitoring in Bangladesh'. Paper presented at the United Nations/International Astronautical Federation Workshop on 'Expanding the User Community of Space Technology Application in Developing Countries', Melbourne, Australia, 24-27, September. p. 2.

Collins, A.E. (2009a) 'The people centred approach to early warning systems and the 'Last Mile'. World Disaster Report 2009: Focus on Early Warning, Early Action. Chapter 2. pp. 3968. International Federation of the Red Cross and Red Crescent Societies (IFRC), Geneva.

Collins, A.E. (2009b) Disaster and Development. Perspectives in Development Series. Routledge, London.

CRED (Centre for Research in the Epidemiology of Disasters) (2007) 'EM-DAT 2007: The OFDA/CRED International Disaster Database'. Université Catholique de Louvain, Brussels. http://www.em-dat.net (accessed on 22 April 2007).

DFID (Department for International Development) (2005) Disaster Risk Reduction: A Development Concern. Policy Briefing Paper. DFID, London.

Dove, M.R. and M.H. Khan (1995) 'Competing constructions of calamity-the April 1991 Bangladesh cyclone'. Population and Environment. 16(5). pp. 445-471.

Edgeworth, R. and A.E. Collins (2006) 'Self-care as a response to diarrhoea in rural Bangladesh: Empowered choice or enforced adoption?' Social Science and Medicine. 63(10). pp. 2686-2697.

Haider, R. (ed.) (1992) Cyclone '91 Revisited: A Follow-up Study. Bangladesh Centre for Advanced Studies (BCAS), Dhaka.

Haque, C.E. (1995) 'Climatic hazards warning process in Bangladesh-Experience of, and lessons from the 1991 April cyclone'. Environmental Management. 19(5). pp. 719-734.

Haque, C.E. (1997) 'Atmospheric hazards preparedness in Bangladesh: a study of warning, adjustments and recovery from the April 1991 cyclone'. Natural Hazards. 16(2-3). pp. 181202. 
Haque, C.E. and D. Blair (1992) 'Vulnerability to tropical cyclones-evidence from the April 1991 Cyclone in Coastal Bangladesh'. Disasters. 16(3). pp. 217-229.

Haque, C.E. and M.Q. Zaman (1993) 'Human responses to riverine hazards in Bangladesh: a proposal for sustainable floodplain development'. World Development. 21(2). pp. 93-107.

Haque C.E. and M.Q. Zaman (1994) 'Vulnerability and response to riverine hazards in Bangladesh: a critique of flood control and mitigation processes'. In A. Varley (ed.) Disaster, Development and Environment. John Wiley \& Sons, London. pp. 65-80.

Hassan, S. (2000) 'Indigenous perceptions, predictions and survival strategies concerning cyclone in Bangladesh'. In N. Ahmed Khan (ed.) Of Popular Wisdom: Indigenous Knowledge and Practices in Bangladesh. Bangladesh Resource Center for Indigenous Knowledge (BARCIK) and Integrated Action Research and Development (IARD, Dhaka. pp. 147-149.

Hewitt, K. (1997) Regions of Risk: A Geographical Introduction to Disasters. Longman, Harlow.

Hilhorst, D. (2004) 'Complexity and diversity: unlocking social domains of disaster response'. In G. Bankoff, G. Frerks and D. Hilhorst (eds.) Mapping Vulnerability: Disasters, Development and People. Earthscan, London. pp. 52-66.

Hilhorst, D. and G. Bankoff (2004) 'Introduction: mapping vulnerability'. In G. Bankoff, G. Frerks and D. Hilhorst (eds.) Mapping Vulnerability: Disasters, Development and People. Earthscan, London. pp. 1-9.

Hoque B.A. et al. (1993) 'Environmental health and the 1991 Bangladesh cyclone'. Disasters. 17(2). pp. 143-152.

Howell, P. (2003) Indigenous Early Warning Indicators of Cyclones: Potential Application in Coastal Bangladesh. Disaster Studies Working Paper No. 6. Benfield Hazard Research Centre, London.

Hutton, D and C.E. Haque (2003) 'Pattern of coping and adaptation among erosion-induced displacees in Bangladesh: implications for hazard analysis and mitigation'. Natural Hazards. 29(3). pp. 405-421. 
Hutton, D. and C.E. Haque (2004) 'Human vulnerability, dislocation and resettlement: adaptation processes of river-bank erosion-induced displaces in Bangladesh'. Disasters. 28(1). pp. 41-62.

IFRC (International Federation of Red Cross and Red Crescent Societies) (2002) World Disaster Report 2002: Focus on Reducing Risk. IFRC, Geneva.

IFRC (2006) World Disaster Report 2006: Focus on Neglected Crisis. IFRC, Geneva.

Ikeda, K. (1995) 'Gender differences in human loss and vulnerability in natural disasters: a case study from Bangladesh'. Indian Journal of Gender Studies. 2(2). pp. 171-193.

ISDR (International Strategy for Disaster Reduction) (2002) Disaster Risk and Sustainable Development: Understanding the Links between Development, Environment and Natural Hazards Leading to Disasters. Background document for the World Summit on Sustainable Development. ISDR, Geneva.

ISDR (2004) Living with Risk: A Global Review of Disaster Risk Reduction Initiatives. ISDR, Geneva.

Islam, M.A. (1974) Human Adjustment to Cyclone Hazards: A Case Study of Char Jabbar. The Natural Hazards Research Working Paper Series. No. 18. Natural Hazards Centre, Boulder, CO.

Jones, R. (2001) 'An environmental risk assessment/management framework for climate change impact assessments'. Natural Hazards. 23(2-3). pp. 197-230.

Khan, A.A. (1974) 'Perception of cyclone hazard and community response in the Chittagong coastal area'. Oriental Geographer. 18(2). p. 1.

Lofland, J. and L. Lofland (1995) Analyzing Social Settings: A Guide to Quantitative Observations and Analysis. Wadsworth, Belmont, CA.

Mallick, F. (2007) 'Planning for sustainable villages for disaster resilience in Bangladesh'. Paper presented at the conference on 'Dealing with Disasters: Resilience, Response and Investigation', Northumbria University, United Kingdom, 5-6 September. 
Mileti D.S. (1987) 'Sociological methods and disaster research'. In R. Dynes, B. de Marchi and C. Pelanda (eds.) Sociology of Disasters: Contribution of Sociology to Disaster Research. Franco Angeli, Milan. pp. 57-69.

MoFDM (Ministry of Food and Disaster Management) (2007) Comprehensive Disaster Management programme. A disaster management programme of the Government of Bangladesh in collaboration with the Department for International Development and the United Nations Development Programme.

Murphy, L. and A. Moriarty (1976) Vulnerability, Coping and Growth from Infancy to Adolescence. Yale University Press, New Haven, CT.

Nizamuddin, K. (1997) Post Project Monitoring Study on the Construction of the Multipurpose Cyclone Shelter. Phase 1. Department of Geography and Environment, University of Dhaka, Bangladesh.

Ohiduzzaman, Md. (1993) Socio-economic and Environmental Effects of the 1991 Cyclone in Coastal Bangladesh: A Local Level Analysis. Unpublished Masters in Urban and Regional Planning (MURP) thesis, Bangladesh University of Engineering and Technology (BUET), Dhaka.

Paton, D. and D. Johnston (eds.) (2006) Disaster Resilience: An Integrated Approach. Charles Thomas Publishers, Springfield, IL.

Paul, B.K. (1984) 'Perception of and adjustment to floods in Jamuna Floodplain, Bangladesh.' Human Ecology. 1(12). pp. 3-19.

Quarantelli, E.L. (2002) 'The Disaster Research Center (DRC) field studies of organized behaviour in the crisis time period of disasters'. In. R.A. Stallings (ed.) Methods of Disaster Research. Xlibris Corporation, Philadelphia, PA. pp. 94-126.

Rahman, M.O. and M. Bennish (1993) 'Health related responses to natural disasters: the case of the Bangladesh cyclone of 1991'. Social Science and Medicine. 36(7). pp. 903-904.

Ray-Bennett, N. et al. (2010) 'Exploring the meaning of health security for disaster resilience through people's perspectives in Bangladesh'. Health and Place. In press. 
Reuters News Agency (2008) 'Bangladesh cyclone survivors struggle with cold, rain'. http://reliefweb.int/rw/rwb.nsf/db900sid/SIRU-7BA2YQ?OpenDocument\&rc=3\&emid=TC2007-000208-BGD (accessed on 27 January 2008).

Sillitoe, P. (2001) 'What know natives?: local knowledge in development'. Grassroots Voice. IV(1). p. 3.

Smit, B., I. Burton, R.J.T. Klein and J. Wandel (2000) 'An anatomy of adaptation to climate change and variability'. Climate Change. 45(1). pp. 223-251.

Smit, B. and J. Wandel (2006) 'Adaptation, adaptive capacity and vulnerability'. Global Environmental Change. 16(3). pp. 282-292.

Twigg, J. and M. Bhatt (1998) Understanding Vulnerability: South Asian Perspective. Intermediate Technology Publications, London.

UNDP (United Nations Development Programme) (2004) Reducing Disaster Risk: A Challenge for Development. Bureau of Crisis Prevention and Recovery, UNDP, New York, NY. p. 146.

UNISDR (United Nations International Strategy for Disaster Reduction) (2005) The Hyogo Declaration. World Conference on Disaster Reduction, Kobe, Hyogo, Japan, 18-22 January.

Weichselgartner, J. (2001) 'Disaster mitigation: the concept of vulnerability revisited'. Disaster Prevention and Management. 10(2). pp. 85-94.

White, G.F. (ed.) (1974) Natural Hazards: Local, National, Global. Oxford University Press, New York, NY.

Wisner, B., P. Blaikie, T. Cannon and I. Davis (2004) At Risk: Natural Hazards, People's Vulnerability and Disasters. Second edition. Routledge, London.

World Bank (2005) Natural Disaster Hotspots: A Global Risk Analysis. Disaster Risk Management Series. No. 5. World Bank, Washington, DC. 
Zaman, M.Q. (1988) The Socioeconomic and Political Dynamics of Adjustment to Riverbank Erosion Hazard and Population Resettlement in the Brahmaputra Jamuna Floodplain. PhD dissertation, University of Manitoba, Winnipeg, MB.

${ }^{1}$ Due to the surge height of the 1991 cyclone, Sandwip Island was divided into badly affected areas, moderately
affected areas and less affected areas. Badly affected areas were inundated by more than 12 feet of surge and
covered 50 per cent of the total area and 40 per cent of the total population of the island. Moderately affected
areas were inundated by between seven and 12 feet of surge and covered 30 per cent of the total area and 35
per cent of the total population of the island. Less affected areas were inundated by between zero and six feet of
surge and covered 20 per cent of the total area and 25 per cent of the total population of the island (Alam, 2002).

${ }^{2}$ According to BUET and BIDS (1992), the risk zone extends from the coastline (sea coast or riverbank) to an inland limit up to which surge water can reach. The high risk area includes a strip of land within the risk zone extending from the coastline up to a limit where the depth of storm surge inundation may reach one metre. The latter criterion was selected based on the experiences of survivors during past storm surge inundations. It has been reported by people in this area and observed by the authors that an adult could force her/his way through water as long as the depth of water remains below waist height.

${ }^{3}$ There are 64 districts in Bangladesh. A district is the second largest administrative unit, and it is considered a vital unit of government administration, consisting of several thanas. A thana comprises several unions, and several villages form a union. A typical village in Bangladesh contains between 30 and 500 households (BBS, 2002).

${ }^{4}$ In villages of Bangladesh, several families—usually the same paternal people or long-trusted familiar peoplelive in a Bari type of settlement comprising one or more houses.

${ }^{5}$ Samaj is a formal social organisation responsible for solving small disputes, cooperation with regard to marriage events involving Samaj members, sharing of some material assets, religious festivals, or organising the burial of a deceased Samaj member.

${ }^{6}$ According to law (regarding the allocation of new areas), priority is given to those farmers, including tenants and labourers, who lost their lands due to river erosion, families who lost members during the 1971 War of Liberation, and families of widowed or abandoned women with an adult son or daughter to be married.

${ }^{7}$ Every morning in the madrassas, boys and girls aged between five and 14 years usually learn the rules and norms of Islam and the Holy Quran from religious teachers.

${ }^{8}$ The Disaster and Development Centre (DDC) has been exploring the meaning of risk, resilience and security through this approach for a number of case studies in different parts of the world. 
${ }^{8}$ The Disaster and Development Centre (DDC) has been exploring the meaning of risk, resilience and security through this approach for a number of case studies in different parts of the world.

${ }^{9}$ The good work of the Bangladesh Cyclone Preparedness Programme and the many aid agencies that have contributed to reducing the impacts of cyclones in the region is nonetheless acknowledged. 